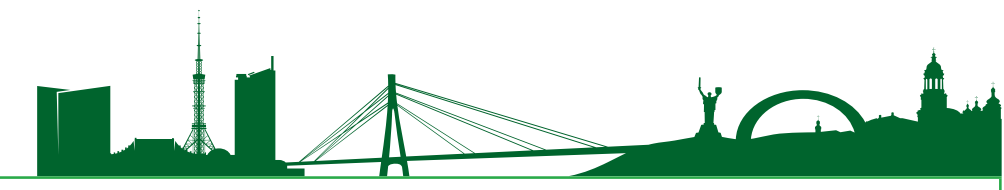

Doi: https://doi.org/10.33644/scienceandconstruction.v27i1.1

UDC 662.613.11

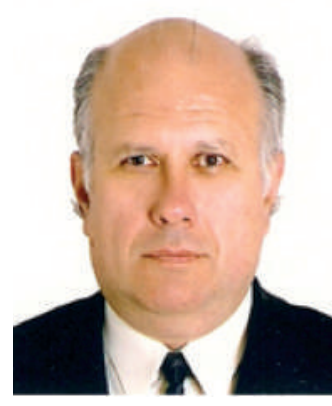

\section{SHEINICH L.}

Dr, Prof., Head of Dept., the State Enterprise "The State Research Institute of Building Constructions", Kyiv, Ukraine, e-mail: schein@ndibk.gov.ua tel. +38 (044) 248-88-73

ORCID: 0000-0002-7684-9495

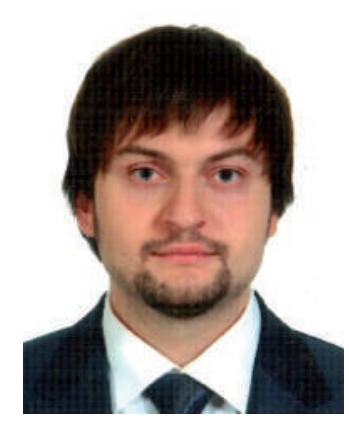

MYKOLAIETS M.

PhD, Head of Laboratory, the State Enterprise "The State Research Institute of Building Constructions", Kyiv, Ukraine, e-mail: mmikolaets@gmail.com tel. +38 (044) 224-78-79 ORCID: 0000-0002-8823-3401

\title{
THE RESEARCH AND USE IN CONSTRUCTION OF THE BY-PRODUCTS FROM THE THERMAL POWER PLANT HYDRAULICALLY REMOVED ASH CLASSIFICATION
}

\begin{abstract}
Today the environment protection is one of the most important issues in the world. The utilization of accumulating industrial waste is an up-todate area of construction research. The paper suggests a method for processing an electricity production waste, namely an ash from the hydraulic removal in the thermal power plant (TPP). The special classification by fractions of ashes from the hydraulic removal allows to receive such products as iron-containing product, fine sand (coarse filler), aluminosilicate hollow microsphere, and product with pozzolanic activity (fine filler).

The experts of the State Enterprise "The State Research Institute of Building Constructions" and "Engineering Company "Perspective"" have conducted a series of studies on the obtained products properties and chemical composition, as well as on determining the fractional composition of each product. The density and specific surface area were evaluated, and each product binding properties control was performed. It was found
\end{abstract}

that the aluminosilicate hollow microsphere and the product with pozzolanic activity had binding properties, and hardened mortars based on these materials were insoluble in water. Chemical analysis showed that in each of the products, except for iron-containing one, oxides of silicon and aluminum predominated. The iron containing product had a high content of iron oxides and by its composition was close to magnetite.

The carried-out studies show that the products obtained during the hydraulic ash removal at TPP have a wide range of applications, both in the construction industry and in the chemical, mining, and metallurgical industries. In construction, these materials can be widely used as active mineral additives in the grinding of cements, or as additives improving the concrete mixtures and concretes properties. The iron-containing product is applicable in the special ultraheavy concretes manufacture.

KEYWORDS: aluminosilicate, ash, filler, magnetite, pozzolana, classification, flotation, slag 


\section{nd 11 rand}

\section{ДОСЛІДЖЕННЯ І ЗАСТОСУВАННЯ ВТОРИННИХ ПРОДУКТІВ ВІД ФРАКЦІО- НУВАННЯ ЗОАИ ГІДРОВИДААЕННЯ ТЕПАОЕАЕКТРОСТАНЦІЙ В БУДІВНИЦТВІ}

\section{АНОТАЦІЯ}

Захист навколишнього середовища, на сьогодні, є однією із важливих проблем у цілому світі. Утилізація промислових відходів, які накопичуються, є актуальним напрямком дослідницьких робіт. У статті запропоновано спосіб переробки відходу від виробництва електроенергії - золи гідровидалення теплоелектростанцій (TEC). Спеціальна класифікація за фракціями золи гідровидалення дає змогу отримати декілька окремих продуктів: продукт залізовмісний, пісок дрібнодисперсний (грубий наповнювач), мікросфера алюмосилікатна порожниста, продукт 3 пуцолановою активністю (дрібний наповнювач).

Співробітниками Державного підприємства «Державний науково-дослідний інститут будівельних конструкцій» та «Інжинірінгова компанія «Перспектива»» було проведено ряд досліджень властивостей та хімічного складу отриманих продуктів, а також встановлення фракційного складу кожного із продуктів. Було визначено густину та питому поверхню, а також встановлено наявність в'яжучих властивостей у кожного продукту. Виявлено, що мікросфера алюмосилікатна порожниста та продукт 3 пуцолановою активністю мають в’яжучі властивості, затверділі розчини на основі цих матеріалів не розчиняються у воді. Хімічний аналіз показав, що в кожному з продуктів, окрім залізовмісного, переважають оксиди кремнію та алюмінію. Продукт залізовмісний має високий вміст оксидів заліза та за складом наближається до магнетиту.

Проведені дослідження показали, що отримані продукти із золи гідровидалення ТЕС мають широку сферу застосування, як в будівельній галузі господарства, так і в хімічній, гірничовидобувній, металургійній промисловостях. В будівництві ці матеріали можуть широко застосовуватись в якості активних мінеральних добавок при помелі цементів, в якості добавок для покращення властивостей бетонних сумішей та бетонів. Продукт залізовмісний - при виготовленні надважких спеціальних бетонів.

КЛЮЧОВІ СЛОВА: алюмосилікат, зола, наповнювач, магнетит, пуцолана, сепарація, флотація, шлам

\section{INTRODUCTION}

The use of by-products is a pressing challenge worldwide, as it allows, inter alia, to solve the of environmental protection issue of the accumulation of thermal power plants ((TPP) fuel combustion products in the dumps. One of such large quantity by-products that pollute the environment is the waste, including fly ash or ash and slag, from the electricity production at TPP.

Addressing the problem of such wastes utilization, the TOV "Engineering Company "Perspective"" suggested the solution based on their recycling.

In compliance with the proposed technology, some types of mixtures are received during the classification by fractions of the ash from the TPP hydraulic removal. The products dispersion is a multistage process carried out by the method of flotation envisaging the buoying of ultralight particles and their collection by a defoamer, the particles classification in hydrocyclones, and magnetic separation. This process results in the following products:

The iron-containing product;

Fine sand (coarse filler);

Aluminosilicate hollow microsphere;

Product with pozzolanic activity (fine filler).

\section{ANALYSIS OF RECENT RESEARCH AND PUBLICATIONS}

Many scientists have worked on the problem of using a TPP fly-ash as an active mineral additive. For instance, N.V. Mishutin [1] and L.I. Dvorkin [2] note that the active mineral additives introduction to the concrete composition increases the artificial concrete stone durability. According to the works by K.K. Pushkariova and A.A. Plugin [3], L.I. Dvorkin [4; 5] and P.V. Kryvenko [6] the mineral supplements usually have a positive effect on the concrete properties, because their particles are finer than Portland cement and can display a pozzolanic activity during cements hardening [7].

In A.S. Pryimachenko's work [8] the positive experience of the fly ash usage in the manufacture of sulfate-resistant concretes is presented. The work of E.A. Krylov [9] describes how the removed ash was effectively used to improve the aerated concrete physical characteristics, which is confirmed in practice.

\section{TASK DEFINITION}

The main task of the research was to determine the physical and chemical properties of the products obtained from the TPP hydraulic ash removal. It was also important to determine the fields for each product effective use.

In parallel with the above tasks, the utilization problem of the wastes accumulated during the TPP operation was also solved.

\section{MAIN TEXT AND RESULTS}

As a result of the research of 4 products (mixtures) classified from the ash of the TPP hydraulic removal, their sieve composition was found, as well as the chemical analysis and some physical properties determination were carried out.

The results of each mixture sieving, and mixtures fractional compositions are shown in Table 1. 


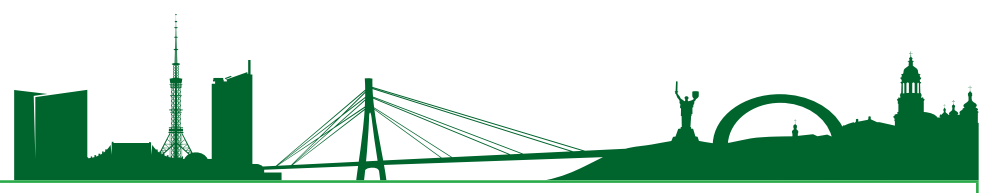

The hardening time and water resistance were determined for the fine filler and aluminosilicate hollow microsphere. The study was performed according to the DSTU B B.2.7-100 method [10].

The normal dough consistency determination for a product with pozzolanic activity (fine filler) is based on the following:

$400 \mathrm{~g}$ of fine aggregate $+200 \mathrm{~g}$ of lime putty $(50 \%$ moisture) $+14.25 \mathrm{~g}$ of ground gypsum stone. Water consumption is $185 \mathrm{~g}$. Dough is of normal consistency of $46.25 \%$.

The normal dough consistency determination for an aluminosilicate hollow microsphere is based on the following: $200 \mathrm{~g}$ of aluminosilicate hollow microsphere $+100 \mathrm{~g}$ of lime putty (50\% moisture) $+7.13 \mathrm{~g}$ of ground gypsum stone. Water consumption is $185 \mathrm{~g}$. Dough is of normal consistency of $46.25 \%$.

If the water consumption is $464 \mathrm{~g}$ per $400 \mathrm{~g}$ of aluminosilicate hollow microsphere, the dough is of normal consistency of $116.0 \%$.

The further tests were performed using a Vick's device with a pestle. In both cases, the end of hardening was observed after 24 hours.

The water resistance tests of the hardened sample
Table 1 - Sieve analysis

\begin{tabular}{|c|l|c|c|c|c|c|}
\hline \multirow{2}{*}{ No } & Material name & \multicolumn{5}{|c|}{ Sieve № residue percentage } \\
\cline { 3 - 7 } & \multicolumn{1}{|c|}{2} & 0.315 & 0.250 & 0.160 & 0.08 & sieve 0.08 \\
\hline 1 & \multicolumn{1}{|c|}{2} & 4 & 5 & 6 & 7 \\
\hline 1 & $\begin{array}{l}\text { Iron-containing } \\
\text { product }\end{array}$ & - & 1.5 & 1.6 & 6.9 & 89.9 \\
\hline 2 & $\begin{array}{l}\text { Fine sand } \\
\text { (coarse filler) }\end{array}$ & 0.9 & 3.0 & 3.8 & 47.8 & 44.4 \\
\hline 3 & $\begin{array}{l}\text { Aluminosilicate } \\
\text { hollow } \\
\text { microsphere }\end{array}$ & 1.5 & 25.2 & 13.3 & 26.9 & 33.0 \\
\hline 4 & $\begin{array}{l}\text { Product with } \\
\text { pozzolanic } \\
\text { activity (fine } \\
\text { filler) }\end{array}$ & - & 0 & 0 & 3.25 & 96.70 \\
\hline
\end{tabular}

Table 2 - Physical and technical indicators

\begin{tabular}{|c|l|c|c|c|c|}
\hline $\begin{array}{c}\text { Num- } \\
\text { ber }\end{array}$ & \multicolumn{1}{|c|}{ Mixture type } & $\begin{array}{c}\text { Selling } \\
\text { humidity, } \\
\text { not more } \\
\text { than, } \%\end{array}$ & $\begin{array}{c}\text { Bulk } \\
\text { consistency, } \\
\mathrm{g} / \mathrm{cm}^{3}\end{array}$ & $\begin{array}{c}\text { True } \\
\text { consistency, } \\
\mathrm{g} / \mathrm{cm}^{3}\end{array}$ & $\begin{array}{c}\text { Specific } \\
\text { surface, } \\
\mathrm{cm}^{2} / \mathrm{g}\end{array}$ \\
\hline 1 & $\begin{array}{l}\text { Iron-containing } \\
\text { product }\end{array}$ & 1 & 1.79 & 3.50 & 920 \\
\hline 2 & Fine sand & 1 & 1.25 & 2.10 & 1520 \\
\hline 3 & $\begin{array}{l}\text { Aluminosilicate } \\
\text { hollow microsphere }\end{array}$ & 1 & 0.29 & 0.57 & 3380 \\
\hline 4 & $\begin{array}{l}\text { Product with } \\
\text { pozzolanic activity }\end{array}$ & & 0.84 & 2.13 & 5270 \\
\hline
\end{tabular}

on the basis of the fine filler showed that the mixture withstood the test, and no sample erosions were detected.

The water resistance tests of the hardened sample on the basis of the aluminosilicate hollow microsphere showed that there was a slight erosion of the sample, and the edges were blurred.

Table 3 - Chemical compositions

\begin{tabular}{|c|c|c|c|c|c|c|c|c|c|c|c|c|c|}
\hline \multirow{2}{*}{$\begin{array}{l}\text { Mixture } \\
\text { type }\end{array}$} & \multicolumn{13}{|c|}{ Chemical compositions $\%$} \\
\hline & LOI* & $\mathrm{SiO}_{2}$ & $\mathrm{Al}_{2} \mathrm{O}_{3}$ & $\mathrm{Fe}_{2} \mathrm{O}_{3}$ & $\mathrm{FeO}$ & $\mathrm{TiO}_{2}$ & $\mathrm{CaO}$ & $\mathrm{MgO}$ & $\mathrm{SO}_{3}$ & $\mathrm{~K}_{2} \mathrm{O}$ & $\mathrm{Na}_{2} \mathrm{O}$ & $\mathrm{P}_{2} \mathrm{O}_{5}$ & $\mathrm{MnO}$ \\
\hline $\begin{array}{l}\text { Iron- } \\
\text { containing } \\
\text { product }\end{array}$ & $0.8-1.1$ & $\begin{array}{l}20.0- \\
24.0\end{array}$ & $\begin{array}{l}9.0- \\
13.0\end{array}$ & $\begin{array}{l}43.0- \\
46.0\end{array}$ & $\begin{array}{c}9.0- \\
13.0\end{array}$ & $\begin{array}{c}0.31- \\
0.4\end{array}$ & $\begin{array}{c}2.00- \\
3.9\end{array}$ & $\begin{array}{c}2.90- \\
3.5\end{array}$ & $\begin{array}{l}0.02- \\
0.05\end{array}$ & $\begin{array}{l}0.4- \\
0.71\end{array}$ & $\begin{array}{c}0.3- \\
0.6\end{array}$ & $\begin{array}{l}0.1- \\
0.19\end{array}$ & $\begin{array}{c}0.9- \\
1.1\end{array}$ \\
\hline Fine sand & $1.9-2.2$ & $\begin{array}{l}55.0- \\
60.0 \\
\end{array}$ & $\begin{array}{l}20.0- \\
26.0 \\
\end{array}$ & $\begin{array}{c}4.20- \\
4.60 \\
\end{array}$ & $\begin{array}{l}2.1- \\
2.5 \\
\end{array}$ & $\begin{array}{l}0.70- \\
0.95 \\
\end{array}$ & $\begin{array}{c}3.15- \\
3.3 \\
\end{array}$ & $\begin{array}{l}1.55- \\
1.72 \\
\end{array}$ & $\begin{array}{c}0.03- \\
0.06 \\
\end{array}$ & $\begin{array}{l}2.2- \\
2.45 \\
\end{array}$ & $\begin{array}{c}0.61- \\
0.85 \\
\end{array}$ & $\begin{array}{l}0.35- \\
0.55 \\
\end{array}$ & $\begin{array}{c}0.08- \\
0.1 \\
\end{array}$ \\
\hline $\begin{array}{l}\text { Aluminosi- } \\
\text { licate } \\
\text { hollow } \\
\text { micro } \\
\text { sphere }\end{array}$ & $\begin{array}{c}0.26- \\
0.35\end{array}$ & $\begin{array}{c}60.5- \\
64.1\end{array}$ & $\begin{array}{l}25.3- \\
28.1\end{array}$ & $\begin{array}{l}1.00- \\
1.20\end{array}$ & $\begin{array}{c}1.56- \\
2.1\end{array}$ & $\begin{array}{c}0.65- \\
0.8\end{array}$ & $\begin{array}{l}1.00- \\
1.21\end{array}$ & $\begin{array}{c}1.11- \\
1.3\end{array}$ & $\begin{array}{l}0.05- \\
0.15\end{array}$ & $\begin{array}{l}3.35- \\
3.71\end{array}$ & $\begin{array}{l}0.41- \\
0.81\end{array}$ & $\begin{array}{c}0.1- \\
0.2\end{array}$ & $\begin{array}{c}0.03- \\
0.04\end{array}$ \\
\hline $\begin{array}{l}\text { Product } \\
\text { with } \\
\text { pozzolanic } \\
\text { activity }\end{array}$ & $\begin{array}{l}3.0- \\
14.0\end{array}$ & $\begin{array}{l}43.2- \\
47.0\end{array}$ & $\begin{array}{c}18.0- \\
19.0\end{array}$ & $\begin{array}{c}4.30- \\
4.90\end{array}$ & $\begin{array}{c}1.4- \\
1.8\end{array}$ & $\begin{array}{c}0.76- \\
1.0\end{array}$ & $\begin{array}{c}2.55- \\
3.1\end{array}$ & $\begin{array}{c}1.15- \\
1.4\end{array}$ & $\begin{array}{c}0.06- \\
0.08\end{array}$ & $\begin{array}{l}1.6- \\
2.0\end{array}$ & $\begin{array}{c}0.54- \\
0.95\end{array}$ & $\begin{array}{c}0.56- \\
0.89\end{array}$ & $\begin{array}{c}0.09- \\
0.11\end{array}$ \\
\hline
\end{tabular}

*Loss on ignition 
The results of some physical properties determination are shown in Table 2.

The mixtures chemical compositions and losses during firing are given in Table 3 .

The material samples chemical analysis shows the following:

1) in the iron-containing product composition the iron oxides (trivalent and divalent) mixture and magnetite itself dominate $-55 \%$; there is a small fraction (32\%) of the aluminosilicates mixture. Alkali content ( $\mathrm{Na} 2 \mathrm{O}$ equivalent) is $0.82 \%$;

2) the coarse filler mixture composition is dominated by the silicon oxides $(58 \%)$ and aluminum oxides $(23 \%)$. Alkali content $(\mathrm{Na} 2 \mathrm{O}$ equivalent) is $2.3 \%$;

3) in the aluminosilicate hollow microsphere the silicon oxides and aluminum oxides shares increase up to $63 \%$ and $26 \%$, respectively. Alkali content ( $\mathrm{Na} 2 \mathrm{O}$ equivalent) is $2.96 \%$;

4) in the fine filler mixture (product with pozzolanic activity) composition the silicon oxides (47\%) and aluminum oxides $(21 \%)$ dominate as well. Alkali content (Na2O equivalent) is $1.97 \%$.

Given the above alkalis content in the obtained products, it is necessary to use these materials with caution in concrete and reinforced concrete structures operated in conditions favorable for alkaline corrosion.

As a result of research, it was found that the products of the hydraulically removed ash classification can be used in various sectors of the economy.

Aluminosilicate hollow microsphere can be used in:

1) the construction-as an active mineral admixture for cements; active mineral admixture in the manufacture of solutions improving the lime mortars properties, liquid mortars, plaster mixtures, concretes, including light and cellular concretes; active mineral admixture for the coatings of insulating, roofing and soundproof materials;

2) the ceramic and refractory industry - as an active mineral admixture in the manufacture of refractory materials, light refractories, fireclay products, refractory bricks, abrasive highly porous materials;

3) the chemical industry - as an active mineral admixture in the manufacture of thermoplastic composition for marking roads and airfields with asphaltic and bituminous concrete pavements; filler for the polymeric materials, paints and varnishes production.

The iron-containing product can be used:

- in the manufacture of special concretes;

- for the production of ferrosilicon, cast iron, steel, raw material for powder metallurgy;

- in the manufacture of special heavy concrete with high average consistency;

- in the minerals processing as a weighting material.
Fine sand can be used:

- as an aggregate in the mortars and concretes production, including the light and cellular concretes;

- as a filler in the polymeric materials, paints and varnishes production.

Product with pozzolanic activity can be used:

- as an active mineral admixture for cements;

- as an active mineral admixture in the manufacture of mortars, concretes, including light and cellular concretes;

- as a filler in the polymeric materials, paints and varnishes production.

\section{CONCLUSIONS}

1. The use and processing of the hydro-removal ash allows to solve the problem of recycling the electricity production wastes at the TPPs of Ukraine.

2. Based on a special technology of screening and classification of hydraulic removal ash the following products are received:

- iron-containing product;

- fine sand (coarse filler);

- aluminosilicate hollow microsphere;

- product with pozzolanic activity (fine filler).

3. The products of hydraulic removal ash classification that are proposed by the company TOV "EC "Perspective"'" have a wide range of applications both in the construction industry and in the chemical, mining and metallurgical industries.

4. Physical and chemical studies have shown that the obtained products can be used in construction as fillers and aggregates for concretes, special concretes, as well as active mineral additives in the cement production. The aluminosilicate hollow microsphere and product with pozzolanic activity have the binding properties that can be practical for reducing the cement consumption and improving the technological properties of concrete and mortar mixtures and of concretes.

5. To determine the mixtures (obtained sieving products) optimal content in heavy, light or cellular concrete and mortars the further research on the components selection should be carried out using the specific materials under the conditions of ensuring the concrete and mortar required quality in products and structures and necessary reinforcement corrosion resistance.

\section{БІБАІОГРАФІЧНИЙ СПИСОК}

1. Мишутин Н.В. Пути повышения сроков эксплуатации гидротехнических и специальных сооружений на основе опыта ремонта плавучих железобетонных сооружений. Вісник Одеської державної академії 


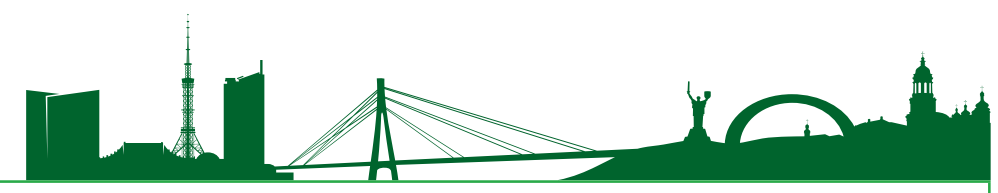

будівництва та архітектури. 2014. Вип. №54. С. 238-244.

2. Дворкин Л.И. Применение промышленных отходов в производстве строительных материалов. Бетони і розчини з використаннямефективних добавок та відходівпромисловості. Збірникматеріалів VII науково-технічного семінару. Структура, властивості та склад бетону. Київ: ТОВ «Полипром», 2008. С. 4-21.

3. Пушкарьова К.К., Зайченко М.М., Плугін А.А. та ін. Енергоресурсозберігаючі мінеральні в'яжучі речовини та композиційні будівельні матеріали на їх основі. Київ: «За друга», 2014. 272 с.

4. Дворкин Л.И., Макаренко Р.Н., Кизима В.П. Цементно-зольные бетоны с добавками полифункциональных модификаторов (ПФМ) для покрытия полов промышленных и гражданских зданий. Ровно: УГУВХП, 2002. 124 c.

5. Дворкин А.И., Дворкин О.А., Корнейчук А.И. Әффективные цементно-зольные бетоны. Ровно, 1998. 196 с.

6. Кривенко П.В., Гоц В.И., Пушкарева К.К. и др. Цементы и бетоны на основе топливных зол и шлаков. Киев: ООО «ИПК «ЭкспрессПолиграф», 2012. 255 с.

7. Wan H., Shui Z., Lin Z. Analysis of geometric characteristics of GGBS particle particles and their influences on cement properties. Cem. Concr. Res. 2004. №34(1). C. 133-137. DOI: https:/doi.org/10.1016/S0008-8846(03)00252-7

8. ПриймаченкоА.С. Високоміцнісульфатостійкі бетони, модифіковані алюмосилікатними добавками: дис. ... канд. техн. наук: 05.23.05. Київ, 2017. 134 с.

9. Крилов Е.О. Вплив модифікації твердої складової на властивості неавтоклавного газобетону: автореф. дис. ... канд. техн. наук: 05.23.05. Одеса, 2020. 23 с.

10 ДСТУ Б В.2.7-100-2000 (ГОСТ 25094-94). Будівельні матеріали. Добавки активні мінеральні для цементів. Методи випробувань. [Чинний від 01.07.2000]. Вид. офіц. К. $11 \mathrm{c}$.

\section{REFERENCES}

1. Mishutin, N.V. (2014). Ways to increase the hydraulic and special structures service life based on the experience of floating reinforced concrete structures repair. Collection of scientific works "Bulletin of Odessa State Academy of Civil Engineering and Architecture”, 54, 238244.

2. Dvorkin, L.I. (2008). The industrial waste use in the production of construction materials. Concretes and mortars using effective additives and industrial waste. Collection of materials of the VII Scientific and Technical Seminar. Structure, properties and composition of concrete, 4-21. Kyiv: TOV "Poliprom".

3. Pushkariova, K.K., Dvorkin, L.I., Hradoboiev, O.V., Zaichenko, M.M., \& Kahanovskyi, O.S. (2014). Energy-saving mineral binders and composite building materials on their basis. Kyiv: "Zadruha".

4. Dvorkin, L.I., Makarenko, R.N., \& Kyzyma, V.P. (2002). Cement-ash concretes with of multipurpose modifiers (MPM) additives for covering the industrial and civil buildings floors. Rivne: NUWEE.

5. Dvorkin, L.I., Dvorkin, O.L., Korneichuk, L.I. (1998). Effective cement-ash concretes. Rivne, 1998.

6. Kryvenko, P.V., Pushkariova, E.K., Hots, V.I., \& Kovalchuk, H.Yu. (2012). Cements and concretes based on fuel ash and slag. Kyiv: OOO "IPK “Ekspress-Poligraph".

7. Wan, H., Shui, Z., \& Lin, Z. (2004). Analysis of geometric characteristics of GGBS particles and their influences on cement properties. Cement and Concrete Research, 34(1), 133-137. DOI: https://doi.org/10.1016/S0008-8846(03)00252-7

8. Pryimachenko, A. S. (2017). High-strength sulfate-resistant concretes modified with aluminosilicate additives. (PhD thesis). Kyiv.

9. Krylov, E. O. (2020). The effect of the solid component modification on the properties of non-autoclaved aerated concrete. (PhD thesis). Odesa.

10. Building materials. Active mineral additions for cements. Test methods: DSTU B V.2.7100-2000 (GOST 25094-94). (01.07.2000).

Стаття надійшла до редакції 11.11.2020 року 